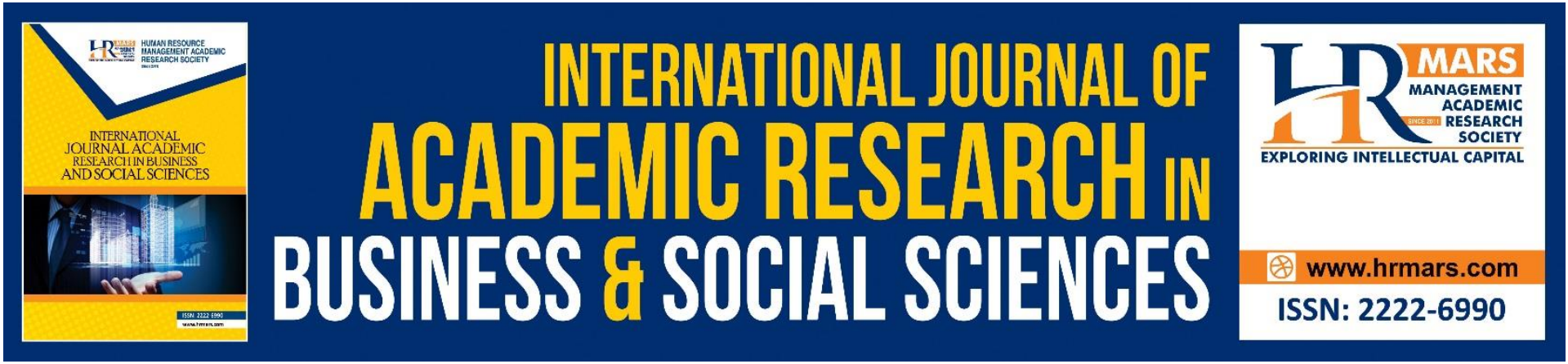

\title{
A Systematic Review of E-Learning in Teaching And Learning of Speaking Skills
}

Joan Lim Ker Shin, Melor Md Yunus

To Link this Article: http://dx.doi.org/10.6007/IJARBSS/v11-i4/9245

DOI:10.6007/IJARBSS/v11-i4/9245

Received: 02 February 2021, Revised: 04 March 2021, Accepted: 25 March 2021

Published Online: 24 April 2021

In-Text Citation: (Shin \& Yunus, 2021)

To Cite this Article: Shin, J. L. K., \& Yunus, M. M. (2021). A Systematic Review of E-Learning in Teaching And Learning of Speaking Skills. International Journal of Academic Research in Business and Social Sciences, 11(4), 725-740.

Copyright: (c) 2021 The Author(s)

Published by Human Resource Management Academic Research Society (www.hrmars.com)

This article is published under the Creative Commons Attribution (CC BY 4.0) license. Anyone may reproduce, distribute, translate and create derivative works of this article (for both commercial and non-commercial purposes), subject to full attribution to the original publication and authors. The full terms of this license may be seen at: http://creativecommons.org/licences/by/4.0/legalcode

Vol. 11, No. 4, 2021, Pg. 725 - 740

http://hrmars.com/index.php/pages/detail/IJARBSS

JOURNAL HOMEPAGE

Full Terms \& Conditions of access and use can be found at

http://hrmars.com/index.php/pages/detail/publication-ethics 


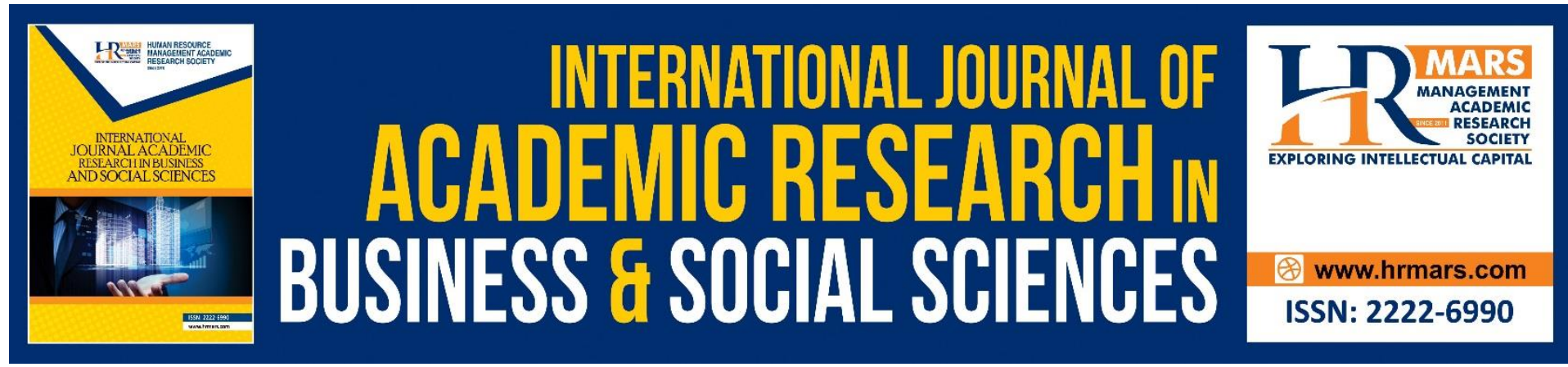

\title{
A Systematic Review of E-Learning in Teaching And Learning of Speaking Skills
}

\author{
Joan Lim Ker Shin, Melor Md Yunus \\ Faculty of Education, Universiti Kebangsaan Malaysia (UKM)
}

\begin{abstract}
In light of the progress of information and communication technology development, elearning is emerging as the paradigm of modern education. However, there is very little to none of the past systematic review that had been conducted on the users' attitudes towards e-learning and the effects of e-learning in teaching and learning of speaking skills. Therefore, the purpose of this systematic review is to synthesise the findings of studies related to users' attitudes towards e-learning and also the effects of e-learning in teaching and learning of speaking skills in any levels of education. This systematic review used 32 full-text journal articles from the year 2016 until 2020 from ERIC and JURN. Results of this review showed that the most used method in exploring the users' attitude towards e-learning and the effects of e-learning in teaching and learning of speaking skills was quantitative method. Overall, the results of this review showed that $90.9 \%$ of the users have positive attitudes towards elearning and $100 \%$ of the past studies revealed that the use of e-learning has positive effects in teaching and learning of speaking skills despite some limitations.
\end{abstract}

Keywords: E-Learning, Attitude, Effects, Teaching and Learning, Speaking Skills, Education

\section{Introduction}

The influence of globalisation has brought tremendous changes to our education system. With the advancing information age, the emerging technology tools have created new opportunities for educational institutions and makes every space a possible learning space for everyone. A good example that could be seen is the increasing use of digital tools for teaching and learning that have gradually substituted the conventional tools like handouts, books, paper and pens (Steelcase, 2020). The COVID-19 pandemic is also another evidence to the dramatic change in education. It was reported in the media that online learning is at a distinctive rise, whereby teaching is undertaken on digital platforms due to the COVID-19 that has resulted in schools shut all across the world (Li \& Farah, 2020). Also, in light of the progress of information and communication technology (ICT) development, the wide use of digital tools in teaching and learning is a paradigm change in modern education (Alphin, Chan \& Lavine, 2017).

This method of learning is known as electronic learning (e-learning). To be precise, Whyte (2017) explains that e-learning is the use of electronic technologies which include a dozen software and platforms for teaching and learning that can be used with computers or mobile devices to create learning experiences. In addition, Horton (2011) further added that 
e-learning could emerge in a variety of forms like mobile learning, social learning and virtual classroom courses. The great advantage of e-learning is its ability to affirm and advance the relationships between learners and instructors as well as to overcome the limitations of time and space through the asynchronous and synchronous learning network model (Sun et al., 2008).

Today, there is no shortage of tools available for teachers who use e-learning in education particularly in the teaching and learning of speaking skills because the inclusion of digital tools in lesson delivery is becoming a norm. Teachers could utilise the digital tools available to provide input to the learners and create active interaction with them. According to Arkorful and Abaidoo (2015), e-learning is considered among the best methods to teach and learn speaking skills as it is highly flexible when limitation of time and place are highly considered. It is also a very efficient way of delivering lessons online because teachers could easily access to a vast amount of information through a variety of online resources. According to Oluborode and Olofintuyi (2014), e-learning is also perceived as a fun way of teaching and learning speaking skills as it could increase the learners' motivation and encourage collaboration through the use of interesting multimedia platforms.

Despite the rapid development of e-learning, there is a need to investigate the users' attitudes towards e-learning and the effects of e-learning in teaching and learning of speaking skills. In this instance, teachers and learners would be the key determinant because they are the major implementors in this process. Their attitude would also be the primary factor to be considered in determining its smooth implementation. Meanwhile, administrator in schools would be benefitted from this review as they could identify the users' challenges and help to find solutions so as to maximise the effectiveness of e-learning. Stakeholders could also get down to the users' view and perspective to fulfil their needs in order to make the implementation a smooth and effective one.

There were several studies that had been done on the users' attitude towards elearning and its implementation in teaching and learning of speaking skills in various contexts (Rafiq, Hussain \& Abbas, 2020; Yilmaz, 2017; Banditvilai, 2016). However, there is very little to none of the past systematic review that had been conducted on the users' attitude towards e-learning and the effects of e-learning in teaching and learning of speaking skills (Rodrigues et al., 2019; Kaliisa \& Picard, 2017). Therefore, the purpose of this review is to synthesise the findings of studies related to a) users' attitude towards e-learning and also b) the effect of elearning in teaching and learning of speaking skills in any levels of education. The researcher would fist define e-learning in the context of teaching and learning of speaking skills. Then, two research questions: a) What are the users' attitude towards e-learning? and b) What are the effects of e-learning in teaching and learning of speaking skills? were formulated to guide the researcher in choosing appropriate articles to review. Then, the researcher would synthesise the findings from the articles to answer both of the research questions.

\section{E-Learning in Teaching \& Learning of Speaking Skills}

E-learning is a worldwide trend in educational institutions (Arkorful \& Abaidoo, 2015). According to Littlejohn and Pegler (2007), e-learning is an umbrella term used to describe 'networked learning', 'online-learning', 'computer-assisted learning' and 'web-based instruction'. They added that e-learning is the combination of electronic environments and physical teaching spaces across time zones in real time. Also, Arkorful, and Abaidoo (2015) reveal that e-learning is the use of ICT to enable the access to online learning and teaching 
resources. This is in line with Algahtani (2011) who perceived e-learning as a method of learning based on the use of computer and Internet.

According to Safran, Helic and Gütl (2007), e-learning supports the socio constructivist pedagogical strategy where learners could interact and learn together using technologies to perform speaking activities like discussion or collaborative projects. This would put learners at the centre of learning thus make learning more meaningful for them. This is also evident when Safran, Helic and Gütl (2007) further mentioned that e-learning tool such as podcast is used in teaching and learning of speaking skills to involve learners directly in the production of learning content. Precintha et al. (2019) also identified a few e-learning applications to teach speaking skills that appeal to learners like Flip grid, Voki, Blendspace and Video scribe.

According to Clark (2003), the use of these e-learning applications could increase the learners' motivation and support learner-centred approach which is one of the features of successful learning. This is in line with a study done by Mansor and Yunus (2017) on the use of Blendspace. The results revealed that $60 \%$ of the undergraduates find learning English speaking skills more fun. Meanwhile, Manty et al. (2017) found in their research that Voki application has helped the undergraduates to improve their speaking skills and they showed positive attitudes towards the use of Voki in language learning. These educational applications make it seamless for the users to share information between the virtual classroom and their favourite applications to make learning possible beyond limits. In short, it could be concluded that e-learning is a teaching and learning method that utilises digital tools and Internet to facilitate learning process regardless of the boundary of distances.

\section{Method}

In this systematic review, the researcher applied the five steps of method used behind the process of carrying out a systematic review that was proposed by Khan et al. (2003).

\section{Step 1: Framing Questions for A Review}

According to Sun and Chen (2016), the rapid expansion and growth of e-learning started since the advent of the World-Wide Web (WWW) in 1991. Meanwhile, the current COVID-19 pandemic has further accelerated the development of e-learning environments within educational institutions. Therefore, this systematic review aims to analyse the users' attitudes towards e-learning and also the effects of e-learning in teaching and learning of speaking skills in any levels of education. In line with this, two research questions are formulated: a) What are the users' attitudes towards e-learning? and b) What are the effects of e-learning in teaching and learning of speaking skills?

\section{Step 2: Identifying Relevant Work}

The second step in a systematic review is identifying relevant work. In this step, the researcher used two main databases namely ERIC and JURN to capture as many relevant citations as possible and to identify primary studies on users' attitudes towards e-learning and the effects of e-learning in teaching and learning of speaking skills. ERIC is an online digital library of education research and information whereas JURN is another database used to search for millions of free academic articles and books across multiple disciplines. Based on the search from these two databases, the researcher chose only up-to-date studies that were published between 2016 and 2020 because an understanding of the current literature is significant for a research study (Maggio, Sewell \& Artino, 2016). As a result, the search using 
the keywords "attitudes towards e-learning" and "e-learning and speaking skills" in ERIC database had resulted in 183 studies published between 2016 and 2020. Then, the researcher removed 78 studies because there is no access to the full text. Next, the second database, JURN, was used to search for relevant work. The search using the keywords "attitudes towards e-learning" and "e-learning and speaking skills" in JURN database had resulted in 109 studies published between 2016 and 2020. This makes up a total of 214 studies when added to the previous results gathered from ERIC database.

\section{Step 3: Assessing the Quality of Studies}

In this systematic review, the researcher has also established inclusion and exclusion criteria for article selection as shown in Table 1 to assess the quality of studies used.

Table 1 Inclusion and exclusion criteria

\begin{tabular}{|c|c|c|}
\hline Factors & Inclusion Criteria & Exclusion Criteria \\
\hline Date & Published between 2016 and 2020 & Published before 2016 \\
\hline \multirow[t]{2}{*}{$\begin{array}{l}\text { Exposure of } \\
\text { interest }\end{array}$} & $\begin{array}{l}\text { 1. Attitude towards the use of e- } \\
\text { learning }\end{array}$ & $\begin{array}{l}\text { 1. Attitude towards the use of e-learning } \\
\text { is not included }\end{array}$ \\
\hline & $\begin{array}{l}\text { 2. The effects of e-learning in } \\
\text { teaching and learning of speaking } \\
\text { skills }\end{array}$ & $\begin{array}{l}\text { 2. The effects of e-learning in teaching } \\
\text { and learning of speaking skills is not } \\
\text { explored. }\end{array}$ \\
\hline Participants & From various levels of education & Not from any levels of education \\
\hline $\begin{array}{l}\text { Reported } \\
\text { outcomes }\end{array}$ & $\begin{array}{l}\text { Access and evaluate the use of e- } \\
\text { learning in teaching and learning of } \\
\text { speaking skills and explore the } \\
\text { users' attitude towards e-learning }\end{array}$ & $\begin{array}{l}\text { Did not access and evaluate the use of e- } \\
\text { learning in teaching and learning of } \\
\text { speaking skills and no reported outcomes } \\
\text { on the users' attitude towards e-leaning }\end{array}$ \\
\hline $\begin{array}{l}\text { Type of } \\
\text { publication }\end{array}$ & Original studies published in journal & Other than journal \\
\hline
\end{tabular}

Based on these inclusion and exclusion criteria, the studies were sorted and only studies that met the inclusion criteria were included whereas studies that clearly met one or more of the exclusion criteria were excluded. In this systematic review, 182 articles which did not meet with the inclusion and exclusion criteria were removed, leaving 32 articles to be included in this review.

\section{Step 4: Summarizing the Evidence}

At this step, the researcher abstracted data from each of the individual primary studies to facilitate the summary presentation of the results to the readers. Two final 'Summary of evidence' tables which include the authors, phenomenon of interest and synthesised findings are presented to answer the two research questions.

\section{Step 5: Interpreting the Findings}

In the last step, the researcher interpreted, discussed and set out the implications for practice or future research from the findings of the systematic review. The researcher also employed content analysis to reveal the trends of the approaches used in the past studies to find out either the studies utilised quantitative, qualitative or mix-method approach. Additionally, the level of participants is also analysed in this review. Table 2 showed the frequency of each approach used among the total of 32 articles. The mostly used approach that had been conducted by previous studies is quantitative approach, followed by mix- 
method and qualitative method. The participants in the studies are mostly university learners as reviewed in Table 3.

Table 2 The approach implemented in past studies

\begin{tabular}{lccc}
\hline \multicolumn{1}{c}{ Databases } & ERIC & JURN & Total \\
Approach & & & 18 \\
\hline Quantitative & 8 & 10 & 5 \\
Qualitative & 5 & 0 & 9 \\
Mixed-method & 4 & 5 & 32 \\
\hline Total & 17 & 15 & \\
\hline
\end{tabular}

Table 3 Participants' level of education

\begin{tabular}{lccc}
\hline \multicolumn{1}{c}{ Databases } & ERIC & JURN & Total \\
Level of learners & & & 1 \\
\hline School learner & 0 & 1 & 31 \\
University learner & 17 & 14 & 32 \\
\hline Total & 17 & 15 & \\
\hline
\end{tabular}

\section{Results}

The articles selected to be synthesised in this systematic review highlighted on two main topics: (i) the users' attitudes towards e-learning and (ii) the effects of e-learning in teaching and learning of speaking skills. Therefore, the results of this systematic review will be discussed in two sections pertaining to the two main topics highlighted in the articles.

\section{Users' Attitude towards E-Learning}

Majority of the past studies ( $n=20,90.90 \%$ ) revealed that the users' attitude towards e-learning is positive and the responses from the users are mostly due to the influence of several factors. The factors influencing the users' attitudes towards e-learning are summarized in Table 4 while the discussion of each author is represented in Table 5.

Table 4 Summarization on the factors influencing users' attitudes towards e-learning

\begin{tabular}{|c|c|}
\hline Influencing Factors & Frequency \\
\hline $\begin{array}{l}\text { Perceived usefulness, perceived ease of use, social influence, quality of life } \\
\text { (TAM Model) }\end{array}$ & 6 \\
\hline Effectiveness of e-learning & 4 \\
\hline Self-efficacy & 4 \\
\hline E-learning experience & 3 \\
\hline Level of innovativeness & 3 \\
\hline Teachers' quality \& designed model of teaching & 2 \\
\hline System Quality & 2 \\
\hline Study method & 1 \\
\hline Academic achievement & 1 \\
\hline Performance expectancy \& effort expectancy (UTAUT Model) & 1 \\
\hline Gender & 1 \\
\hline
\end{tabular}


Table 5 Summary of evidence on the users' attitude towards e-learning

\begin{tabular}{|c|c|c|c|}
\hline No & Authors & Phenomenon of Interest & Synthesised Findings \\
\hline 1. & $\begin{array}{l}\text { Özcan, Gökçearslan } \\
\text { \& Solmaz } 2016\end{array}$ & $\begin{array}{l}\text { Pre-service teachers' attitudes } \\
\text { towards e-learning }\end{array}$ & $\begin{array}{l}\text { 1. Pre-service teachers' levels of } \\
\text { innovativeness positively influence } \\
\text { their attitude towards e-learning. }\end{array}$ \\
\hline 2. & $\begin{array}{l}\text { Iwata, Wang \& } \\
\text { Clayton } 2019\end{array}$ & $\begin{array}{l}\text { Students' perceptions about } \\
\text { the use of digital badges }\end{array}$ & $\begin{array}{l}\text { 1. The use of digital badges can } \\
\text { motivate the students and promote } \\
\text { learning autonomy. }\end{array}$ \\
\hline 3. & $\begin{array}{l}\text { Ikhwan \& Widodo } \\
2019\end{array}$ & $\begin{array}{l}\text { The role of blended learning } \\
\text { based on teacher's perception } \\
\text { with respect to the students' } \\
\text { attitude }\end{array}$ & $\begin{array}{l}\text { 1. Students are getting good scores in } \\
\text { English because they are motivated to } \\
\text { participate in blended learning. } \\
\text { 2. Students' attitude has a positive } \\
\text { correlation with the teacher's } \\
\text { designed model of teaching in } \\
\text { blended learning. }\end{array}$ \\
\hline 4. & $\begin{array}{l}\text { Yalman, Basaran \& } \\
\text { Gönen } 2016\end{array}$ & $\begin{array}{l}\text { Attitudes of students towards } \\
\text { e-learning management } \\
\text { system }\end{array}$ & $\begin{array}{l}\text { 1. Students who preferred individual } \\
\text { work have positive attitudes towards } \\
\text { e-learning due to the individualized e- } \\
\text { learning environments. }\end{array}$ \\
\hline 5. & $\begin{array}{l}\text { Chaka \& Govender } \\
2017\end{array}$ & $\begin{array}{l}\text { Students' perceptions and } \\
\text { readiness towards mobile } \\
\text { learning }\end{array}$ & $\begin{array}{l}\text { 1. Students had positive perceptions } \\
\text { towards mobile learning. } \\
\text { 2. Students' positive perceptions } \\
\text { towards mobile learning were } \\
\text { influenced by four constructs namely } \\
\text { performance expectancy, effort } \\
\text { expectancy, social influence and } \\
\text { mobile learning conditions. }\end{array}$ \\
\hline 6. & Alzahrani 2017 & $\begin{array}{l}\text { Students' knowledge of e- } \\
\text { resources and attitudes } \\
\text { towards e-resources }\end{array}$ & $\begin{array}{l}\text { 1. Students' attitude towards e- } \\
\text { resources is positively influenced by } \\
\text { their knowledge of e-resources. }\end{array}$ \\
\hline 7. & Al-Juda 2017 & $\begin{array}{l}\text { Distance learning students' } \\
\text { evaluation of e-Learning } \\
\text { system }\end{array}$ & $\begin{array}{l}\text { 1. The students' positive attitude } \\
\text { towards e-learning system has a } \\
\text { positive relationship with the } \\
\text { effectiveness of e-learning system } \\
\text { provided by the university. }\end{array}$ \\
\hline 8. & Iqbal 2017 & $\begin{array}{l}\text { Students' perception towards } \\
\text { m-learning }\end{array}$ & $\begin{array}{l}\text { 1. Students generally have positive } \\
\text { attitudes towards m-learning due to } \\
\text { the factor of perceived usefulness but } \\
\text { students from different degree } \\
\text { programs have different perception } \\
\text { towards the usage of mobile phones } \\
\text { in educational context. }\end{array}$ \\
\hline 9. & $\begin{array}{l}\text { Oyaid \& Alshaya } \\
2019\end{array}$ & $\begin{array}{l}\text { Students' views, perceptions, } \\
\text { and future intentions towards } \\
\text { e-books }\end{array}$ & $\begin{array}{l}\text { 1. Almost all of the students found the } \\
\text { use of e-book beneficial. } \\
\text { 2. They were really satisfied with the } \\
\text { interactivity and the highlighting, }\end{array}$ \\
\hline
\end{tabular}


10. Karaaslan \& Kılıç 2019

11. Eltahir 2019

12. Faramarzi, Tabrizi \& Chalak 2019

13. Yakubu 2019

14. Revythi \& Tselios 2019

15. Kisanga 2016

16. Yorganci 2017

17. Ozturk, Ozturk \& Rasit 2018

18. Wasserman \& Migdal 2019
Students' attitudes towards blended language courses

The perspective on the efficiency and usability of elearning courses

Learners' perceptions and attitudes towards second language (L2) vodcasting tasks in an e-learning project

The effect of quality antecedents on the acceptance of learning management systems (LMS)

Assessing behavioural intention to use e-learning based on Technology Acceptance Model (TAM) Teachers' attitudes towards elearning

Students' self-efficacy and attitudes towards mobile learning

The relationship between prospective teachers' readiness and satisfactions about web-based distance education

Teachers' attitudes in online and traditional training courses changing of font size and hyperlink features.

1. High-achievers had positive attitudes towards all learning aspects.

2. Low-achievers required more interaction and study management support.

1. There is a great need to conduct more training for freshman students on how to use Moodle while most staff members are satisfied with the Moodle system.

1. Learners viewed the experience as significantly positive and constructive.

2. The application is user-friendly and suitable to be used to teach listening skills.

3. The experience is regarded as enjoyable.

1. Instructor quality and system quality were found to significantly predict the student's behavioural intention to use the LMS.

1. Social norm, system access and self-efficacy significantly affect behavioural intention to use LMS.

1. Teachers have positive attitudes towards e-learning.

2. Their attitude is largely influenced by their computer exposure level.

1. Majority of students had positive attitudes towards m-learning.

2. Gender differences existed in the students' attitudes.

1. The levels of readiness and satisfaction of the prospective teachers were found to be positive because their aims, needs and expectations were met during the program.

1. There was a significant difference in the attitudes towards ICT between online and traditional training courses which correspond to the perceived 
19. Emine \& Kalelioglu 2019

Students' perspective on a fully online course experience

20. Edmondson \& Ward 2017

21. Bahiti \& Farizi 2018 Lecturer' attitudes towards e-

22. Vululleh 2018 learning according to demographic variables

Students' attitudes towards textbook types

Students' e-learning acceptance in developing countries usefulness (PU) component in the TAM model.

1. Students found distance learning educational, efficient, useful, and appropriate for the course.

2. The course taken through distance education helped students to gain computer and internet self-efficacy as well as develop their self-directed learning skills.

1. Students still prefer paperback textbooks.

1. Lecturers' have high attitude towards e-learning and their attitude scores have significant differences with factors of teaching experience and e-learning experience.

1. Student's behavioural intention to accept and use e-learning in developing countries was affected by their perceived usefulness, perceived ease of use, quality of life and social influence.

\section{The Effects of E-Learning in Teaching \& Learning of Speaking Skills}

All of the past studies $(n=10,100 \%)$ revealed that the use of e-learning has positive effects on teaching and learning of speaking skills despite some limitations. The effects of elearning in teaching and learning of speaking skills are summarized in Table 6 and the discussion of each author is represented in Table 7.

Table 6 Summarization of the effects of e-learning in teaching \& learning of speaking skills

\begin{tabular}{lc}
\hline \multicolumn{1}{c}{ Effects of e-learning } & Frequency \\
\hline Improving listening \& speaking in terms of grammar, vocabulary, intonation & 8 \\
and coherence & 2 \\
Motivating & 1 \\
Promoting autonomous learning & 1 \\
\hline
\end{tabular}


Table 7 Summary of evidence on the effects of e-learning in teaching \& learning of speaking skills

\begin{tabular}{|c|c|c|c|}
\hline No & Authors & Phenomenon of Interest & Synthesised Findings \\
\hline 1. & $\begin{array}{l}\text { Mošatová \& } \\
\text { Výškrabková } 2019\end{array}$ & $\begin{array}{l}\text { Developing complex language } \\
\text { skills and cognitive competence } \\
\text { in the distance learning of } \\
\text { Slovak }\end{array}$ & $\begin{array}{l}\text { 1. The use of recordings and essays } \\
\text { in the tutor-supported e-slovak } \\
\text { courses and written or audio } \\
\text { feedback by tutors for each } \\
\text { assignment proved to be motivating. }\end{array}$ \\
\hline 2. & Banditvilai 2016 & $\begin{array}{l}\text { Enhancing students' language } \\
\text { skills through blended learning }\end{array}$ & $\begin{array}{l}\text { 1. Online practice is beneficial to } \\
\text { enhance the four language learning } \\
\text { skills, autonomous learning and } \\
\text { learner motivation. }\end{array}$ \\
\hline 3. & Frolova 2017 & $\begin{array}{l}\text { Electronic means of foreign } \\
\text { language learning in the system } \\
\text { of higher education }\end{array}$ & $\begin{array}{l}\text { 1. E-learning courses can be } \\
\text { delivered on any platform to track } \\
\text { and monitor learners' progress in } \\
\text { the course in an efficient manner. }\end{array}$ \\
\hline 4. & $\begin{array}{l}\text { Watanapokakul } \\
2018\end{array}$ & $\begin{array}{l}\text { The role of edutainment } \\
\text { in the teaching and } \\
\text { learning of English focusing on } \\
\text { students' listening and speaking } \\
\text { skills }\end{array}$ & $\begin{array}{l}\text { 1. Students' listening and speaking } \\
\text { ability increased after they had been } \\
\text { exposed to CULI ZOO. }\end{array}$ \\
\hline 5. & Tseng \& Yeh 2019 & $\begin{array}{l}\text { The effect of video and written } \\
\text { feedback on student } \\
\text { preferences of English-speaking } \\
\text { practice }\end{array}$ & $\begin{array}{l}\text { 1. Written and video feedback was } \\
\text { useful for the learning of grammar } \\
\text { rules, word usage and improvement } \\
\text { of intonation. }\end{array}$ \\
\hline 6. & $\begin{array}{l}\text { Montiel-Chamorro } \\
2018\end{array}$ & $\begin{array}{l}\text { Comparing online English } \\
\text { language learning and face-to- } \\
\text { face English language learning }\end{array}$ & $\begin{array}{l}\text { 1. The online students who } \\
\text { completed all the content of the } \\
\text { course scored higher in English than } \\
\text { those of their face-to-face } \\
\text { counterparts. }\end{array}$ \\
\hline
\end{tabular}

7. Perveen $\mathbf{2 0 1 6}$ Synchronous and asynchronous

1. Asynchronous e-language learning e-language learning

8. Köroğlu \& Çakır 2017

9. AlSaleem 2018
The use of flipped instruction in language classrooms to develop speaking skills

The effect of Facebook activities on enhancing oral communication skills

10. Herrera \& González 2017
Developing the Oral Skill in Online English Courses was quite beneficial for L2 learners but there are also some limitations which could be scaffolded by synchronous sessions.

1. It was found that flipped instruction in language classrooms could help to develop fluency, coherence, lexical resource, grammar, pronunciation and accuracy skills.

1. The suggested Facebook activities in the study were effective on improving participants' oral communication skills.

1. Participants scored higher in the oral final exam and showed 
improvement in terms of grammar, vocabulary, and pronunciation.

\section{Discussions}

Previous studies have highlighted discussion on the users' attitudes towards elearning and the effects of e-learning in teaching and learning of speaking skills. The results of these studies revealed that majority of the users ( $n=22,90.9 \%)$ have positive attitudes towards e-learning and that they were satisfied with e-learning (Özcan, Gökçearslan \& Solmaz, 2016; Iwata, Wang \& Clayton, 2019; Ikhwan \& Widodo, 2019). They perceived the use of e-learning as a method of learning that could motivate the learners and enhance their learning autonomy (Iwata, Wang \& Clayton, 2019; Ikhwan \& Widodo, 2019). This is in line with a study done by Faramarzi, Tabrizi and Chalak (2019). The results revealed that e-learning experience is enjoyable and the application used to facilitate e-learning is also regarded as user-friendly. This could make learning efficient as it is evident when Ikhwan and Widodo (2019) found in their study that the learners' English language achievement was improved after the use of e-learning. In line with this, there is also a past study which showed that distance learning is efficient and useful to the undergraduate students as it helps them to gain computer and internet self-efficacy as well as to improve their self-directed learning skills (Emine \& Kalelioglu, 2019). From these past studies, it can be concluded that the users felt positive towards the use of e-learning. Hence, it is undeniably true that e-learning could be an effective way of learning especially in this globalisation as it could motivate learners to engage actively in learning.

Although majority of the studies have shown positive attitudes towards e-learning, one past study revealed that e-learning is only suitable for students who preferred to work individually as e-learning centred on individualised learning environment (Yalman, Basaran \& Gönen, 2016). Another study done by Karaaslan and Kılıç (2019) showed that e-learning is less suitable for the low achievers although high-achievers were seen to have shown positive attitudes towards e-learning in all learning aspects. The reason is because low achievers need more face-to-face guidance, interaction and learning support, thus this result suggested that the users' academic achievement could have an impact on their attitudes towards e-learning. Additionally, the use of eBook also does not receive positive response from the users and many still prefer paperback textbooks (Edmondson \& Ward, 2017). Meanwhile, there is a past study that shows a need to train the freshman students in using e-learning to improve the efficiency of language learning due to their lack of e-learning experiences (Eltahir, 2019). These imply that users' attitude towards e-learning could be governed by a few influencing factors which play major roles in determining the effectiveness of e-learning.

As seen in the above-mentioned situation, several factors influencing the users' attitudes towards e-learning should be taken into consideration as they could significantly affect the implementation of e-learning in education. Based on the past studies conducted, most of the researchers $(n=6,60 \%)$ agreed that the users' attitudes towards e-learning is highly affected by factors of perceived usefulness, perceived ease of use, social influence and quality of life as suggested by Davis (1989) in Technology Acceptance Model (TAM). This is followed by the effectiveness of e-learning and self-efficacy, as they had contributed $40 \%$ to the influencing factors respectively. Other factors were the users' e-learning experiences and level of innovations because $30 \%$ of the past studies $(n=3)$ found that these factors could influence the users' attitudes towards e-learning. Meanwhile, teachers' quality and the designed model of teaching used as well as the quality of the system had contributed $20 \%$ 
respectively to the influencing factors. On the other hand, study method, academic achievement, gender as well as performance expectancy and effort expectancy as suggested in UTAUT model are also factors identified in the past studies that could influence the uses' attitudes towards e-learning.

In terms of the effects of e-learning in teaching and learning of speaking skill, all of the past studies $(n=10)$ revealed positive results despite some limitations encountered in elearning. Studies showed that the use of ICT tools and digital platforms in e-learning were able to motive the learners, enhance four language skills particularly oral communication skills and encourage autonomous learning (Mošatová \& Výškrabková, 2019; Banditvilai, 2016; AlSaleem, 2018). There were also studies which revealed that the use of e-learning could improve speaking skills in terms of grammar rules, word usage, intonation and pronunciation while some studies suggested that it helped to develop fluency, coherence, lexical resources and accuracy skills (Tseng \& Yeh, 2019; Köroğlu \& Çakır, 2017; Herrera Díaz \& González Miy, 2017). These results indicated that the use of e-learning could be an effective method to motivate and encourage speaking among the learners. It could maximise the learners' learning experiences and leave positive impacts in the teaching and learning of speaking skill. Additionally, there is also another study which shows that e-learning could help to track and monitor learners' progress efficiently (Frolova, 2017). This suggested that e-learning could also assist the teachers in their teaching besides facilitating the learners' learning of speaking skill. However, a study done by Perveen (2016) revealed some limitations of e-learning that need to be scaffolded by synchronous sessions (Perveen, 2016). Hence, it can be seen that elearning could positively affect the teaching and learning of speaking skill but at times, there could also be some limitations.

\section{Conclusion}

As a conclusion, e-learning is emerging as a trend in education with the rapid development of technology. It is widely used in many parts of the world and has become the preferred choice of many people in education. Previous studies showed that majority of the users have positive attitudes towards e-learning as it could enhance learners' autonomy and make learning efficient. In terms of the impact of e-learning on teaching and learning of speaking skills, studies also showed that e-learning could motive the learners and enhance oral communication skills in terms of grammar rules, word usage, intonation, pronunciation, fluency, coherence, lexical resources and accuracy skills. However, there are a few studies which showed the limitations of e-learning. It was found that e-learning could not facilitate group assignment due to its individualised learning environment. Some studies also revealed that e-learning is less appropriate for low achievers as they need more support from the teachers. Overall, this systematic review would benefit the teachers and learners as it enlightens the users on a new alternative in teaching and learning, at the same time, inform the users on its limitation so as to better facilitate the implementation of e-learning in the future. Thus, teachers could plan their teaching and learning strategies while learners would be able to maximise their learning experiences. In short, e-learning could still be an effective method of learning in this globalisation. Majority of the users had showed positive attitudes and response towards e-learning particularly in teaching and learning of speaking skills despite several limitations of e-learning that need to be improved through synchronous sessions. 
Abbreviations List

\begin{tabular}{cl}
\hline Abbreviations & \multicolumn{1}{c}{ Full Form } \\
\hline ICT & information and communication technology \\
L2 & second language \\
LMS & learning management systems \\
PU & perceived usefulness \\
TAM & Technology Acceptance Model \\
WWW & World-Wide Web \\
\hline
\end{tabular}

\section{Availability of Data and Materials}

All data generated or analysed during this study are included in this published article (refer to the reference list).

\section{Competing Interest}

We wish to confirm that there are no known conflicts of interest associated with this publication and there has been no significant financial support for this work that could have influenced its outcome.

\section{Funding}

No funding was received for this work.

\section{Authors' Contributions}

All listed authors had substantially contributed to the analysis and interpretation of data for the work, drafted the work or revising it critically for important intellectual content, approved the final version to be published and agreed to be accountable for all aspects of the work in ensuring that questions related to the accuracy or integrity of any part of the work are appropriately investigated and resolved. We hereby attest that all authors had contributed significantly to the creation of this manuscript. We confirm that the manuscript has been read and approved by all named authors. We confirm that the order of authors listed in the manuscript has been approved by all named authors.

\section{References}

Algahtani, A. (2011). Evaluating the effectiveness of the e-learning experience in some universities in Saudi Arabia from male students' perceptions. https://repository.nu.edu.sa/bitstream/123456789/2244/1/Abdullah'sThesis.pdf

Al-Juda, M. Q. B. (2017). Distance learning students' evaluation of e-learning system in university of Tabuk, Saudi Arabia. Journal of Education and Learning, 6(4), 324-335.

Alphin, J. H. C., Chan, R. Y., \& Lavine, J. (2017). The future of accessibility in international higher education. Pennsylvania: IGI Global.

AlSaleem, B. I. (2018). The effect of Facebook activities on enhancing oral communication skills for EFL Learners. International Education Studies, 11(5), 144-153.

Alzahrani, K. S. (2017). An investigation into Saudi students' knowledge of and attitudes towards e-resources on BBC learning English. English Language Teaching, 10(9), 108130.

Arkorful, V., \& Abaidoo, N. (2015). The role of e-learning, advantages and disadvantages of its adoption in higher education. International Journal of Instructional Technology and Distance Learning, 12(1), 29-42. 
Bahiti, R., \& Farizi, A. (2018). Investigation of lecturer' attitudes towards e-learning according to demographic variables. European Journal of Engineering and Formal Sciences, 2(1), 60-65.

Banditvilai, C. (2016). Enhancing students' language skills through blended learning. Electronic Journal of E-Learning, 14(3), 220-229.

Chaka, J. G., \& Govender, I. (2017). Students' perceptions and readiness towards mobile learning in colleges of education: A Nigerian perspective. South African Journal of Education, 37(1).

Clark, D. (2003). Games and e-learning. Epic Group.

Edmondson, D. R., \& Ward, C. (2017). Students' attitudes towards textbook types: Are students really ready for e-textbooks? Atlantic Marketing Journal, 5(3), 1.

Eltahir, M. (2019). The perspective of students and faculty members on the efficiency and usability of e-learning courses at Ajman university: A case study. Journal of Technology and Science Education, 9(3), 388-403.

Emine, C. A. B. I., \& Kalelioglu, F. (2019). A fully online course experience from students' perspective: Readiness, attitudes and thoughts. Turkish Online Journal of Distance Education, 20(3), 165- 180.

Faramarzi, S., Tabrizi, H. H., \& Chalak, A. (2019). Learners' perceptions and attitudes towards vodcasting tasks in an e-learning project. Teaching English with Technology, 19(3), 3-21.

Frolova, N. (2017). Electronic means of foreign language learning in the system of higher education. Educational Research and Reviews, 12(3), 116-119.

Li, C., \& Farah, L. (2020). The COVID-19 pandemic has changed education forever. This is how. https://www.weforum.org/agenda/2020/04/coronavirus-education-globalcovid19online- digital-learning/

Herrera, D. L. E., \& González, M. D. (2017). Developing the oral skill in online English courses framed by the community of inquiry. Profile Issues in Teachers Professional Development, 19(1), 73-88.

Horton, W. (2011). E-learning by design. New Jersey: John Wiley \& Sons.

Ikhwan, E. J. Q., \& Widodo, P. (2019). Attitude conception: The role of blended learning in environmental education. Online Submission, 2(6), 53-62.

lqbal, S. (2017). Mobile phone usage and students' perception towards m-learning: A case of undergraduate students in Pakistan. The Journal of Distance Education Distance, 32(1).

Iwata, J., Wang, S., \& Clayton, J. (2019). Students' perceptions about the use of digital badges in an online English terminology course: A three-year study. CALL and complexityshort papers from EUROCALL, 199.

Kaliisa, R., \& Picard, M. (2017). A systematic review on mobile learning in higher education: The African perspective. The Turkish Online Journal of Educational Technology, 16(1), 1-18.

Karaaslan, H., \& Kılıç, N. (2019). Students' attitudes towards blended language courses: A case study. Journal of Language and Linguistic Studies, 15(1), 174-199.

Khan, K. S., Kunz, R., Kleijnen, J., \& Antes, G. (2003). Five steps to conducting a systematic review. Journal of the royal society of medicine, 96(3), 118-121.

Kisanga, D. (2016). Determinants of teachers' attitudes towards e-learning in Tanzanian higher learning institutions. International Review of Research in Open and Distributed Learning, 17(5), 109-125. 
Köroğlu, Z. C., \& Çakır, A. (2017). Implementation of flipped instruction in language classrooms: An alternative way to develop speaking skills of pre-service English language teachers. International Journal of Education and Development using ICT, 13(2), 42-55.

Littlejohn, A., \& Pegler, C. (2007). Preparing for blended e-learning. United Kingdom: Routledge.

Maggio, L. A., Sewell, J. L., \& Artino, J. A. R. (2016). The literature review: A foundation for high-quality medical education research.Journal of graduate medical education, 8(3), 297-303.

Mansor, N., \& Yunus, M. M. (2017). The use of blendspace to improve students' Englishspeaking skills. Prosiding Seminar Pendidikan Serantau, 8, 67- 74.

Manty, M., Yunus, M. M., Badusah, J., \& Shah, P. M. (2017). Using Voki to enhance speaking skills. Prosiding Seminar Pendidikan Transdisiplin, 668-672.

Montiel-Chamorro, M. L. (2018). Comparing online English language learning and face-to-face English language learning at El Bosque University in Colombia. https://doi.org/10.25772/CPER-NM95

Mošatová, M., \& Výškrabková, J. 2019. Designing tasks for developing complex language skills and cognitive competence in the distance learning of Slovak as a foreign language. CALL and complexity, 310.

Oluborode, K. D., \& Olofintuyi, I. O. (2014). E-learning and ICT: Advantages and the challenges in a developing educational system. https://www.researchgate.net/publication/281116098_Elearning_and_ICT_Advantages_and_challenges_in_a_developing_educational_sysyte $m$

Oyaid, A., \& Alshaya, H. (2019). Saudi university students views, perceptions, and future intentions towards e-books. Malaysian Online Journal of Educational Technology, 7(1), 69-75.

Özcan, S., Gökçearslan, S., \& Solmaz, E. (2016). Investigation into attitudes of pre-service teachers towards e-learning with respect to their individual innovativeness levels. Online Submission, 6(2), 31-38.

Ozturk, D. S., Ozturk, F., \& Rasit, O. Z. E. N. (2018). The relationship between prospective teachers' readiness and satisfactions about internet-based distance education. Turkish Online Journal of Distance Education, 19(1), 147-162.

Perveen, A. (2016). Synchronous and asynchronous e-language learning: A case study of irtual university of Pakistan. Open Praxis, 8(1), 21-39.

Precintha, R., A., James, P. P., Yong, K. L., \& Yunus, M. M. (2019). Hear me out! Digital storytelling to enhance speaking skills. International Journal of Academic Research in Business and Social Sciences, 9(2), 190-202

Rafiq, F., Hussain, S., \& Abbas, Q. (2020). Analyzing students' attitude towards e-learning: A case study in higher education in Pakistan. Pakistan Social Sciences, 4(1), 367-380

Revythi, A., \& Tselios, N. (2019). Extension of technology acceptance model by using system usability scale to assess behavioral intention to use e-learning. Education and Information Technologies, 24(4), 2341-2355.

Rodrigues, H., Almeida, F., Figueiredo, V., \& Lopes, S. L. (2019). Tracking e-learning through published papers: A systematic review. Computers \& Education, 136, 87-98.

Safran, C., Helic, D., \& Gütl, C. (2007). E-Learning practices and web 2.0. https://telearn.archives- ouvertes.fr/hal-00197260/document 
Steelcase. (2020). How technology is changing education. https://www.steelcase.com/research/articles/topics/technology/how-technology-ischanging-education/

Sun, A., \& Chen, X. (2016). Online education and its effective practice: A research review. Journal of Information Technology Education, 15.

Sun, P. C., Tsai, R. J., Finger, G., Chen, Y. Y., \& Yeh, D. (2008). What drives a successful elearning? An empirical investigation of the critical factors influencing learner satisfaction. Computers \& education, 50(4), 1183-1202.

Tseng, S. S., \& Yeh, H. C. (2019). The impact of video and written feedback on student preferences of English-speaking practice. Language Learning and Technology, 23(2), 145-158.

Vululleh, P. (2018). Determinants of students' e-learning acceptance in developing countries: An approach based on structural equation modeling (SEM). International Journal of Education and Development Using ICT, 14(1).

Wasserman, E., \& Migdal, R. (2019). Professional development: Teachers' attitudes in online and traditional training courses. Online Learning, 23(1), 132-143.

Watanapokakul, S. (2018). A development of a game-based supplementary e-learning program for 'English for veterinary profession I'. Journal of Language Teaching and Learning in Thailand, 55, 178-218.

Whyte, S. (2017). Digital tools for interactive teaching in languages with technology. http://bit.ly/2h6ENUi

Yakubu, M. (2019). The effect of quality antecedents on the acceptance of learning management systems: A case of two private universities in Nigeria. International Journal of Education and Development Using ICT, 15(4).

Yalman, M., Basaran, B., \& Gönen, S. (2016). Attitudes of students taking distance education in theology undergraduate education program towards e-learning management system. Universal Journal of Educational Research, 4(7), 1708-1717.

Yilmaz, R. (2017). Exploring the role of e-learning readiness on student satisfaction and motivation in flipped classroom. Computers in Human Behavior, 70, 251-260.

Yorganci, S. (2017). Investigating students' self-efficacy and attitudes towards the use of mobile learning. Journal of Education and practice, 8(6), 181-185 